\title{
Using dendrochronology to identify species-specific ice storm damage in Delaware
}

\author{
Matthew John Smolnik \\ West Virginia University
}

Follow this and additional works at: https://researchrepository.wvu.edu/etd

\section{Recommended Citation}

Smolnik, Matthew John, "Using dendrochronology to identify species-specific ice storm damage in Delaware" (2004). Graduate Theses, Dissertations, and Problem Reports. 758.

https://researchrepository.wvu.edu/etd/758

This Thesis is protected by copyright and/or related rights. It has been brought to you by the The Research Repository @ WVU with permission from the rights-holder(s). You are free to use this Thesis in any way that is permitted by the copyright and related rights legislation that applies to your use. For other uses you must obtain permission from the rights-holder(s) directly, unless additional rights are indicated by a Creative Commons license in the record and/ or on the work itself. This Thesis has been accepted for inclusion in WVU Graduate Theses, Dissertations, and Problem Reports collection by an authorized administrator of The Research Repository @ WVU. For more information, please contact researchrepository@mail.wvu.edu. 


\title{
Using Dendrochronology to Identify Species-Specific Ice Storm Damage in Delaware
}

\author{
Matthew John Smolnik \\ Thesis submitted to the \\ Eberly College of Arts and Sciences \\ at West Virginia University \\ in partial fulfillment of the requirements \\ for the degree of \\ Master of Arts \\ in \\ Geography \\ Amy Hessl, Ph.D., Chair \\ Desta Fekedulgen, Ph.D. \\ Jennifer Miller, Ph.D. \\ Timothy Warner Ph.D. \\ Department of Geology and Geography \\ Morgantown, West Virginia \\ 2004
}

Keywords: Dendrochronology, Disturbance, Ice storms, Tree Rings 


\title{
Abstract \\ Using Dendrochronology to Identify Species-Specific Ice Storm Damage in Delaware
}

\author{
Matthew John Smolnik \\ Ice storms are recurrent disturbances that alter forest succession and retard tree \\ growth rates throughout North America. Following a 1994 ice storm in Delaware, the \\ Delaware Forest Service established seventy-five study plots to sample four species of \\ trees (southern red oak [Quercus falcate], white oak [Quercus alba], loblolly pine [Pinus \\ taeda], and yellow poplar [Liriodendron tulipifera]) affected by the ice storm. The \\ objectives of this study are to: 1) explore the species-specific growth rates and responses \\ to the ice storm; and 2) determine which of the four species is best suited to provide \\ dendroecological records of past ice storms, using tree-ring measurements of growth \\ reductions from 1994 to 1998. A ground survey was performed to assess the damage to \\ individual trees. The damaged trees were classified into damage class categories based on \\ the percentage of crown limbs broken. Dendrochronology was used to identify the radial \\ growth signature of the ice storm in the tree rings of the four species studied. Overall, \\ yellow poplar was most susceptible to ice storm damage followed by loblolly pine, red \\ oak, and white oak. In general, damage class three trees experienced the greatest \\ reduction in annual radial growth in 1994 followed by damage class two, damage class \\ one, and control plot trees respectively. Yellow poplar had the fastest recovery rate \\ following the storm, followed by white oak, red oak, and loblolly pine respectively. The \\ results of this study suggest that dendrochronology can be a promising method to explore \\ the relationship between ice damage and reduction in tree growth rates at a species- \\ specific level.
}




\section{Acknowledgements}

I would like to thank several persons and agencies for their assistance with this research over the course of the past two years. First and foremost, I would like to thank my chair, Dr. Amy Hessl for the overwhelming effort she put forth by lending ideas about my research design, reading and editing drafts, and for the constant push towards excellence. I also owe a huge thanks to my other committee members, Dr. Desta

Fekedulegn, Dr. Jennifer Miller, and Dr. Tim Warner, for their leadership and guidance in the areas of statistics, exploring GIS spatial analysis, and for tremendous editing and moral support.

Funding for my research came from the USDA Forest Service Northeastern Research Station located in Morgantown, West Virginia. Individuals from this agency who graciously shared their expertise and took time out of their daily schedule to assist me were: Dr. Jim Colbert; Dr. Kurt Gottschalk; Dr. Desta Fekedulegn; and Dave Feicht.

I would also like to thank the Delaware State Forest Service for their support of this project. Dr. Mike Valenti provided useful background information about the study area while he and Henry Poole spent several days in the field collecting the coordinates of each plot, which were used to explore spatial patterns of ice damage.

Last but certainly not least; I would like to acknowledge my wife Cricket. Thanks for putting up with my long hours in the lab and having dinner ready for me when I finally made it home. You listened to what I was working on so intently and without your mental support; this research would not have been possible. I love you! 


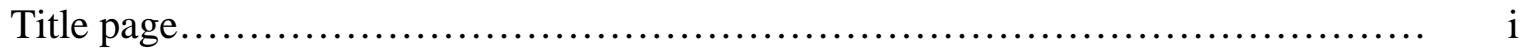

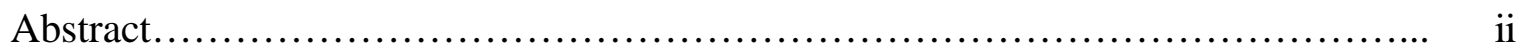

Acknowledgements....................................................

Table of Contents....................................................... iv

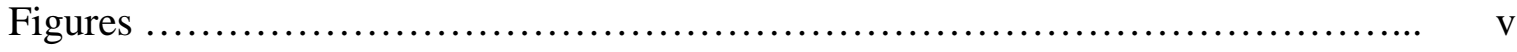

Tables............................................................... vi

Introduction........................................................ 1

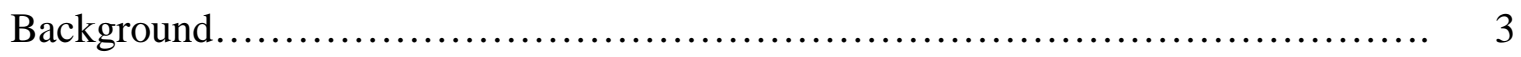

Meteorology of Ice Storms.............................................. 3

Using Tree Rings to Study Ice Storm Damage............................. 4

Study Area........................................................... 6

Methods.............................................................. 7

Field Data Collection.................................................... 7

Laboratory Techniques................................................ 9

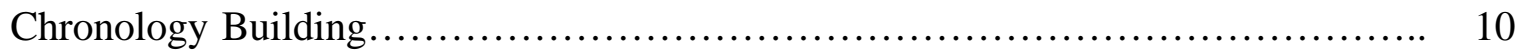

Removing Drought from Tree Rings...................................... 10

Identifying Recorders of Ice Storm Damage................................ 12

Results.............................................................. 13

Species-Specific Patterns of Ice Storm Damage............................. 13

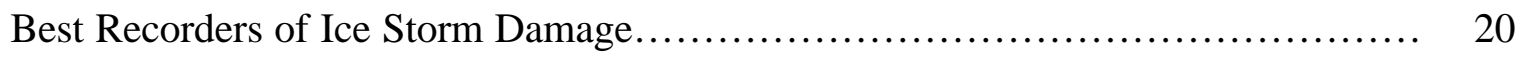

Discussion........................................................ 21

Conclusion.......................................................... 27

References Cited................................................... 29 
Figures:

Figure 1: Typical Development of an Ice Storm in the Atmosphere................ 4

Figure 2: Study Area................................................. 7

Figure 3: Standardized Ring Width versus Year by Damage Class................. 15

Figure 4: Residual versus Year by Damage Class............................. 17

Figure 5: 1994 Percentage Growth Reductions for Individual Species in each

Damage Class ....................................................... 21 
$\underline{\text { Tables: }}$

Table 1: Number of Trees, Cores, and Time Span Covered for each Chronology

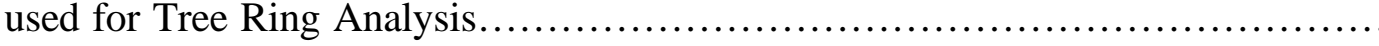

Table 2: Results of Regression Analysis used to Calculate Residuals................ 


\section{Introduction}

Ice storms are a frequent disturbance agent affecting forests throughout North America (Irland, 2000). Damage from ice storms can affect community structure and composition by creating canopy gaps and altering the microclimate near the ground (Wolfe et al., 1949). In such gaps, suppressed saplings grow rapidly (Runkle, 1985; Veblen, 1986), thus accelerating forest succession (Downs, 1938; Lemon, 1961; Whitney \& Johnson, 1984). Ice storm damage can also retard or reinitiate forest succession by opening large gaps and allowing reproduction of early successional species (Siccama et al., 1976; Whitney \& Johnson, 1984). The effect on forest structure, composition, and succession depends on the intensity of the disturbance, the successional age of the forest stand (Glitzenstein et al., 1986), differential species susceptibility to ice damage (Lemon, 1961; Bruederle \& Stearns, 1985), microsite soil and climate conditions (Whitney \& Johnson, 1984), and stochastic patterns of secondary damage (Boerner et al., 1988).

Though their frequency in a particular region is extremely low, ice storms occur throughout the United States and southern Canada with some regularity each year (Bruederle \& Stearns, 1985). Ice storms most commonly develop along a line stretching from northern Texas to Newfoundland associated with slow-moving low-pressure systems where a large temperature difference exists between warm Gulf air and cold Arctic air. The typical ice storm swath is 50 kilometers wide and 500 kilometers long (Heidorn, 2001), although significant variability exists. Ice accretion generally ranges in thickness from a trace, which is characteristic of most storms, to approximately $2.5 \mathrm{~cm}$. However, severe storms may deposit accumulations of ice greater than this. Degree of tree damage is strongly correlated with the weight of glaze ice deposited (Bruederle \& Stearns, 1985), but may also be associated with species. 
In the central and southern Appalachian Mountains, ice storms have been a major natural disturbance in local forests and have significant impacts on the distribution and development of local forest vegetation (Whitney \& Johnson, 1984; Runkle, 1985). Damage caused by ice storms can hinder timber production, reduce the value of forests as wildlife refuges or recreational areas, and exert tremendous economic effects on forest industries, forest landowners, and public forest agencies (Hauer et al., 1993; Rhoades, 1995; Sisinni et al., 1995).

Previous studies of ice storm damage to trees have been conducted following large storms in New York (Seischab et al., 1993), Ohio (Boerner et al., 1988), Virginia (Mou \& Warrillow, 1999), and Wisconsin (Bruederle \& Stearns, 1985), however none of these studies used tree ring methods to evaluate long term effects on tree growth. Lafon and Speer (2002) investigated ice storm damage via tree ring studies, but the focus was on reconstructing previous events rather than evaluating species susceptibility and recovery rates following the disturbance. In addition, previous studies of ice storm damage were conducted where the heterogeneous topography influenced the degrees of ice damage. This study is unique because the study area is characterized by homogeneous topography, which greatly reduces the confounding influence of slope and aspect on ice storm severity and species susceptibility.

After a major ice storm in February 1994, the Delaware State Forest Service performed an aerial survey across the state of Delaware in order to subjectively classify the damage to forested areas caused by the ice storm. Results indicated that the ice impacted 29\% of Delaware's approximate 152,000 ha of forested land, approximately 44,100 ha. The areas affected were classified into one of three aerial damage class categories: light (7466 ha), moderate (14,919 ha), and heavy (23,446 ha). The objective 
of this study is to identify species-specific responses to the 1994 Delaware ice storm using USDA Forest Service data, which was collected statewide four years following the disturbance.

\section{Background}

\section{Meteorology of Ice Storms}

Ice storms originate in the large temperature gradients generated between warm Gulf air and cold Arctic air in slow moving low-pressure systems. In advance of the warm front of an ice storm, warm, moist air moving in from the warm sector overruns the surface cold air to produce the characteristic vertical temperature layering (a low-level temperature inversion with warm air above, and cold below) of the pre-warm front atmosphere. As this air rises in altitude over the cold air, it cools and its water vapor begins to condense. By the time the rising air mass reaches the upper levels of the clouds, approximately $2.3 \mathrm{~km}$, its temperature has dropped below freezing, and much of its condensing vapor forms into ice crystals (Heidorn, 2001). The ice crystals become too heavy to remain suspended in the air and fall through the air masses below. When the temperature of the air mass below is sufficiently warm, the crystals melt and continue their descent to the earth's surface as raindrops. To reach the ground as freezing rain, the raindrops must be supercooled, with the temperatures falling below $0^{\circ} \mathrm{C}$, as they fall through a cold air layer near the ground before striking any surface (Heidorn, 2001). This phenomenon occurs as the raindrop passes through a cold air mass located between the warm air mass above and the earth's surface below. 


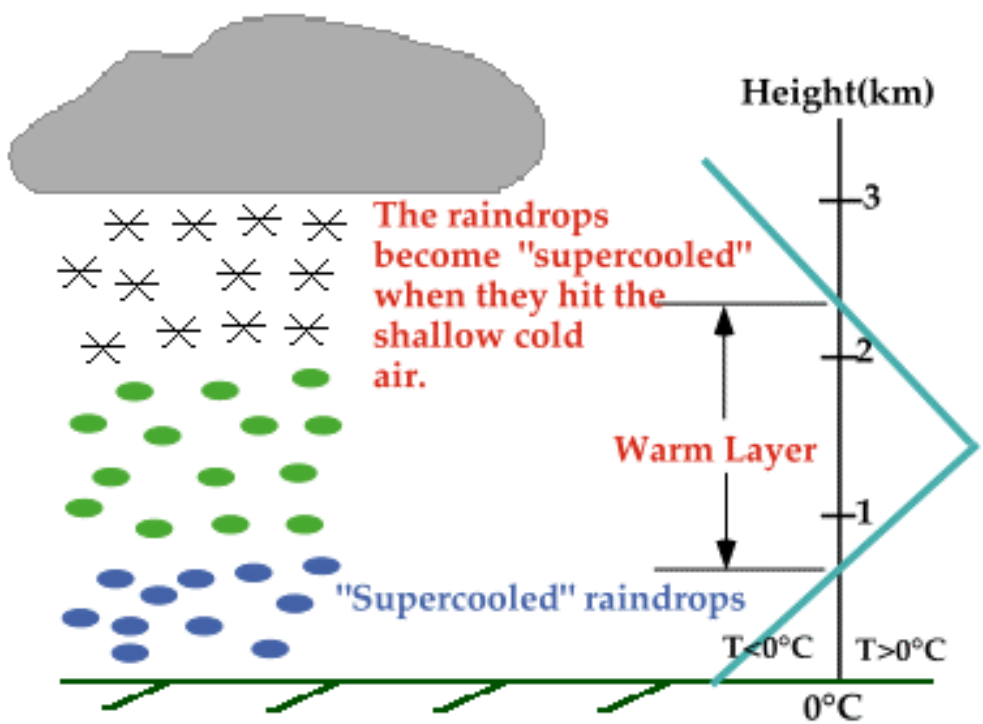

Figure 1. Typical development of an ice storm in the atmosphere. Temperature variation with altitude is represented by the blue line (Department of Atmospheric Sciences, DAS, at the University of Illinois at Urbana Champaign 2003)

In most cases of glaze ice formation, the temperatures of the air, the rainwater, and the surface, are at or slightly below $0^{\circ} \mathrm{C}$, especially in those events where icing is extensive. Glaze ice usually forms when the air temperature near the surface is in the narrow range of $-4^{\circ} \mathrm{C}$ to $0^{\circ} \mathrm{C}$. For heavy glaze ice formation, rain typically falls rapidly as large, slightly supercooled drops, and the rate of freezing at the surface must be slower than the rainfall rate (Heidorn, 2001). The heavy covering of glaze ice leads to significant disturbance events in the forested areas impacted by the storm.

\section{Using Tree Rings to Study Ice Storm Damage}

Dendrochronology has been used for reconstructing disturbance and forest dynamics (Taylor, 1981; Biondi et al.; 1997, Asshof et al.; 1998, Biondi et al., 2002; Burleigh et al., 2002; Bergeron et al., 2002; Smith \& Shortle, 2003), however few studies address ice storms specifically Lafon \& Speer (2002). A wide range of dendroecological 
studies address the impact of insect defoliation (O’Neil, 1963, Swetnam \& Lynch, 1993, Asshof et al., 1998, Speer et al., 2001, Burleigh et al., 2002), a disturbance that has an impact on tree rings similar to that of ice storms. This pattern is typically one of reduced growth for several years after the event. To distinguish between climatic variability such as droughts, and non-climatic events such as insect outbreaks, researchers typically compare tree ring based climate reconstructions and independent meteorological data to time series of known and inferred outbreaks (e.g. Speer et al., 2001). The insect outbreaks create a distinctive ring-width signature often characterized by substantial reduced growth that persists for four or more years (Speer et al., 2001). To reconstruct past ice storm events, Lafon and Speer (2002) removed the noise associated with background climate to distinguish between ice storms and other climatic events in oak forests of southwestern Virginia. They applied regression analysis using Palmer Drought Severity Index (PDSI) values as the independent variable and tree growth as the dependent variable. Lafon and Speer then identified the ice storm signal by comparing the drought free ring width index (the residuals) of each year to the mean from the previous five years. A significant decrease in radial growth was identified as a year during which the ring width index decreased at least 40 percent from the mean of the previous 5 years. A significant increase in radial growth was a year in which the ring width index increased at least 50 percent from the mean of the previous five years. They found two ice storm signals, one of suppression and one of release (Lafon \& Speer, 2002), however, they had only two study sites, and at each site only twenty samples were collected. Collecting a greater number of samples per study site, including larger number of sites, and a wider range of species would help clarify the varied response of tree 
growth to ice storms and would help reduce the noise associated with unrelated events that affect individual trees but not the entire stand (Lafon \& Speer, 2002).

\section{Study Area}

The study area is located in southern New Castle, Kent and northern Sussex Counties, Delaware and is primarily located on state lands managed for recreational activities (Figure 2). The forested stands have not been thinned or actively managed for timber stand improvement (TSI). New Castle, Kent, and Sussex Counties have a moist continental climate characterized by seasonal fluctuations in temperature with warm moist summers and moderately cold winters (Strahler \& Strahler, 2000). Mean annual temperature for the counties range from $13.1^{\circ} \mathrm{C}$ to $13.5^{\circ} \mathrm{C}$, and the average total annual precipitation range from $110 \mathrm{~cm}$ to $112 \mathrm{~cm}$ for a 30 year time period (1960-1990) (National Climatic Data Center, 2003).

New Castle, Kent, and Sussex Counties are part of the oak-pine forest region, which is a transitional region between the southeastern evergreen forest and the central deciduous forest (Braun, 1950). Common species of trees located in the study area include: southern red oak (Quercus falcate), white oak (Quercus alba), loblolly pine (Pinus taeda), yellow-poplar (Liriodendron tulipifera), red maple (Acer rubrum), dogwood (Cornus florida), and sweet gum (Liquidambar styraciflua). The natural northern limit of loblolly pine is located within Sussex County (Ireland \& Matthews, 1974) and pure stands of loblolly pine are rare in Kent County due to the latitude of the area (Ireland \& Matthews, 1971). The soils of these three counties are Oxisols, which are highly weathered soils dominated by stable iron and aluminum oxides. Oxisols are a 
result of long-term adjustments to prevailing soil water and soil temperature conditions (Strahler \& Strahler, 2000).

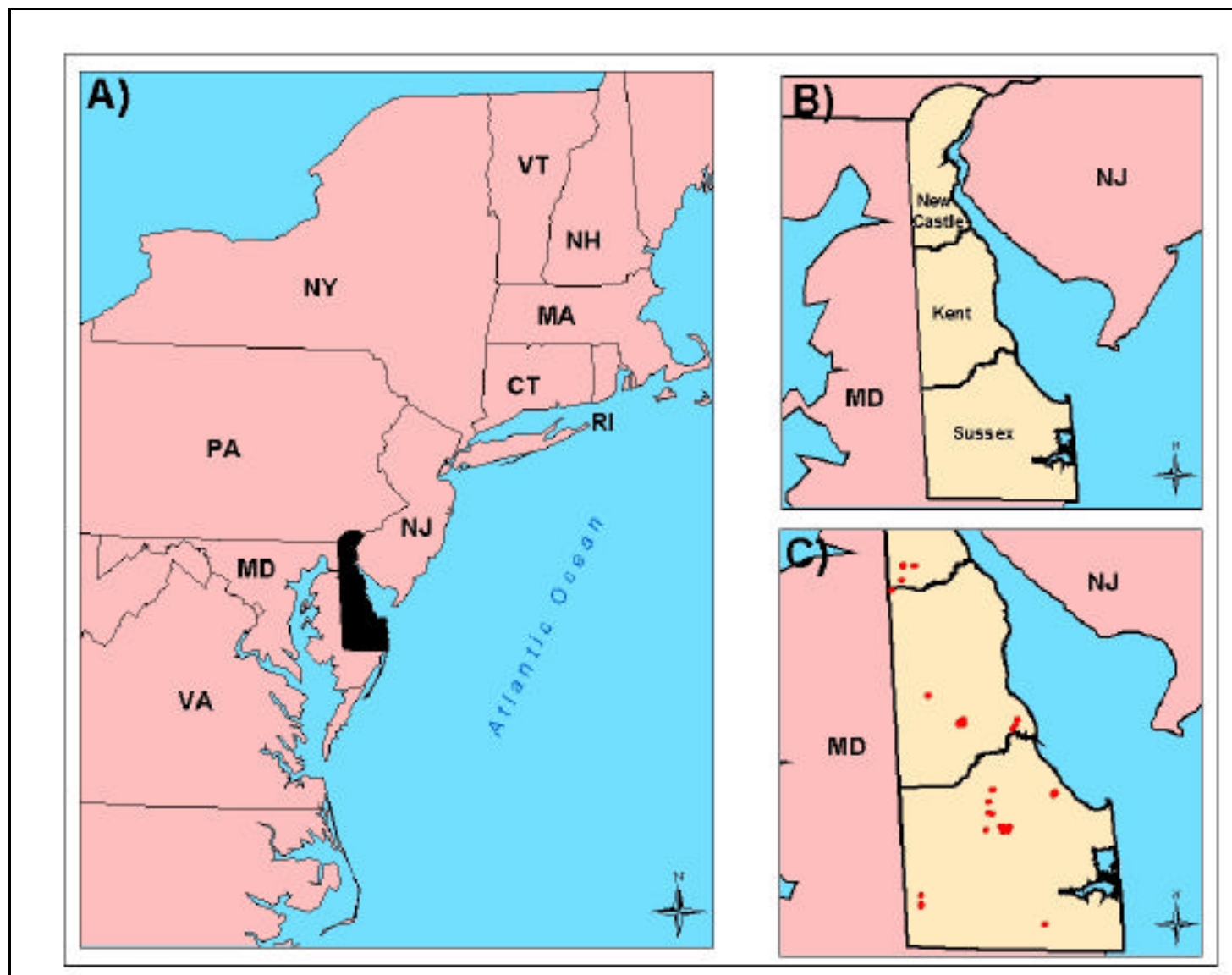

Figure 2: Study area: A) shows the general location of Delaware in the eastern United States; B) shows the counties within the state of Delaware; C) shows the locations of the seventy five study plots (red circles).

\section{Methods}

\section{Field Data Collection}

An aerial survey was performed by the Delaware State Forestry Department in order to subjectively place damaged forest stands into four damage class categories. The 
resulting map was used to identify areas where varying degrees of damaged trees may be located. Ground surveys were performed in 1994 to objectively assess individual tree damage in the damage classes defined by the aerial map. Seventy-five plots were established to determine the damage to four major tree species; (southern red oak [Quercus falcate], white oak [Quercus alba], loblolly pine [Pinus taeda], and yellow poplar [Liriodendron tulipifera]). The goal in establishing each study plot was to incorporate trees in three crown ratio classes, five diameter classes, and four tree species within the area of the plot. DBH was broken into 5 different classes: $25.4-30.3 \mathrm{~cm}$; $30.4-$ $35.3 \mathrm{~cm} ; 35.4-40.3 \mathrm{~cm} ; 40.4-45.3 \mathrm{~cm} ; 45.4-50.8 \mathrm{~cm}$. The strata of the forested stands were classified into four classes: dominant; codominant; intermediate; and overtopped. Crown ratio was categorized into three groups: $21-30 \%, 31-40 \%$, and $41-50 \%$. Trees with damage caused by rot, conks, disease, and insect outbreaks were avoided to insure that the damage to the study trees was associated with the ice storm. A single tree was selected to serve as the center of the plot. From this single tree a 30-meter radius was established for selecting additional trees within the plot. Trees selected for the study had a DBH between 25.4 and $50.8 \mathrm{~cm}$, existed in the dominant or co-dominant strata, had a crown ratio between $20 \%$ and $50 \%$, and damage (excluding ice storm related injuries) was below Forest Service Health Monitoring severity standards (Colbert \& Onken, 1999). All trees representing the four study species that met these criteria and were within the 30-meter radius were included in the study. Between 2 and 27 trees were sampled within each plot, resulting in 786 total trees sampled.

The ground survey of the study plots revealed pockets of trees with various levels of damage within a single aerial damage class so damaged trees were individually assessed and placed into one of the four damage classes (0- no damage to very light, 1- 
light, 2-moderate, and 3-severe) based on the percentage of crown limbs broken (0-4\%, $5-33 \%, 34-66 \%$, and $67-100 \%$ respectively). Twenty of the seventy-five study plots were established as control plots, and were chosen because they were not affected by or received minimal damage from the ice storm; trees within these plots were all classified as damage class 0. A total of 786 trees (200 white oak, 186 southern red oak, 212 loblolly pine, and 188 yellow poplar) were sampled from the seventy-five plots. USDA Forest Service and Delaware Forest Service employees extracted two increment cores at breast height from each tree between December 1998 and April 1999.

During March of 2004, Delaware State Forest employees collected the coordinates of the center tree for each of the seventy-five study plots using a global positioning system (GPS). These data were later incorporated into a GIS (ESRI ArcGIS 8.3) and used to identify the locations of the seventy-five study plots.

\section{Laboratory Techniques}

Once tree cores were brought back to the USDA Forest Service Northeastern Research Station in Morgantown, West Virginia, each sample was individually mounted, air-dried and then sanded with 320, 400, 800, and 1200 grit sandpaper. The sanding enabled the annual ring boundaries to be viewed with the aid of a microscope. The increment core samples were counted and then crossdated using marker years. Following dating, ring widths were measured using a measuring stage and binocular microscope to determine annual growth increments to an accuracy of $0.001 \mathrm{~mm}$. Crossdating was checked statistically using COFECHA to evaluate cross-dating accuracy (GrissinoMayer, 2001). 
A small percentage $(2.3 \%)$ of the cores were not included in the analysis due to broken or twisted samples, or samples in which the annual growth ring boundaries were not visible.

\section{Chronology Building}

The program ARSTANL (Cook \& Holmes, 1986) was used to standardize the individual tree ring series and remove significant temporal autocorrelation from the chronologies. The process of standardizing tree ring width series is necessary to remove age-related trends in growth but maintain variability due to other causes, such as drought and disturbance. To standardize the tree ring width series I applied a 50-year cubic smoothing spline to each measured ring width series and then divided the ring width values by the value of the fitted curve to produce tree ring indices. A 50-year smoothing spline retains 50 percent of the variance over a 50-year period and 99 percent of the variance over a 16-year period. This method removes long-term trends while retaining nearly all annual to decadal-scale variation (Lafon \& Speer, 2002).

In order to determine which species is the best recorder of ice storm events I used the data from all seventy-five plots, but the chronologies were grouped by species and damage class. Each of the four species of trees was represented in four different damage classes, yielding sixteen different ring width chronologies.

\section{Removing Drought from Tree Rings}

Radial tree growth in the mid-Atlantic may be affected by drought (Baker \& Langdon, 1990; Orwig \& Abrams, 1997; Fekedulegn et al., 2003), so I used two methods to separate the ice storm signal from the drought signal: 1) graphical comparison and 2) 
regression analysis. I used graphical comparison to compare the damage class zero trees (located in control plots) to the three other damage classes, by species. For the graphical comparison, I used the chronologies for the four species from each damage class (16 total chronologies), and plotted the standardized ring width index (1989-1998) over time for each of the four species. If unusual climatic conditions occurred in 1994, all of the plots would have been affected and would have exhibited a decline in radial growth for 1994.

Tree species that are susceptible to drought would likely show a decrease in ring width when available moisture is limited. Previous research on yellow poplar has indicated a high level of sensitivity to drought (Fekedulegn et al., 2003), while similar studies on red oak and white oak indicate these species are less likely to be affected by climatic variability (Orwig \& Abrams, 1997, Fekedulegn et al., 2003). Loblolly pine can also be affected by limited moisture leading to a loss of vigor and growth in older trees (Baker \& Langdon, 1990). Therefore, damage class zero yellow poplar and loblolly pine ring width indices would be indicative of whether climatic variability affected tree growth in this area during 1994 or subsequent years.

In order to quantitatively maximize the signal caused by ice storms, the background noise associated with climate was removed using regression analysis (e.g. Lafon \& Speer, 2002). I incorporated data from 1968 to 1998 in order to have a substantial temporal period on which to perform regression analysis, but focused on a smaller temporal period (1989 to 1998) for species-specific analysis of ice storm damage. As the dependent variable, I used the standardized annual ring width index for each species in each of the four damage classes. For the independent variable, I used the averaged monthly value of the PDSI from region two in Delaware for the 12 months prior to September of the ring formation. PDSI is frequently used in dendrochronology and is 
often strongly correlated with tree ring indices in eastern North America (Stahle et al., 1985, Jenkins \& Pallardy, 1995). PDSI is a measure of meteorological drought that incorporates precipitation, runoff, soil moisture, and potential evapotranspiration (Oladipo, 1985). The advantage of using this index is that it is standardized to local climate in order to emphasize relative moisture conditions, but the performance of PDSI in the western United States has been poor due to its inability to calculate water supplies locked up in snow (Wells et al., 2004). Regression models were developed for all sixteen chronologies using the equation:

\section{Standardized Ring Width $=$ Y intercept $+($ PDSI value $)($ coefficient $)$}

The remaining residuals created through regression analysis should be "drought free" but retain the ice storm signal.

\section{Identifying Recorders of Ice Storm Damage}

The species of tree that is best suited to capture the ice storm signal in radial growth will exhibit the largest decline in annual radial growth the year of the disturbance. To quantitatively identify growth suppression or release events, I compared the 1994 drought-free residual for each species in each damage class to the mean residual value from the previous five years. To eliminate all negative values I added a value of one to all of the residuals (e.g. Lafon \& Speer, 2002). I divided the 1994 residual by the previous five-year mean, and then multiplied the quotient by 100 . The resulting values indicate the percentage change in radial growth in 1994 for each species in each of the four damage classes. Comparing each climate-free growth series among all four species identifies the species that are the most susceptible to ice storm damage (the largest percentage growth reduction or suppression in 1994). 


\section{Results}

\section{Species Specific Patterns of Ice Storm Damage}

ARSTANL was used to create chronologies for each species in each of the four damage classes. A total of 94,110 tree rings and 786 trees were measured from the four species (Table 1). The number of trees, cores, and temporal period for all species in the four damage classes, varied between species but each chronology averaged 48 trees and 96 cores. Once the tree ring widths were standardized and chronologies were developed, a ten-year period (1989-1998) was selected for each species in each damage class to further investigate the response to ice damage during the year of the storm and for the following four years.

Table 1: Number of trees, cores, and time span covered for each chronology used for tree ring analysis.

\begin{tabular}{lccc}
\hline \multicolumn{2}{c}{ Chronology Trees, Cores, and Time Span Covered } \\
Chronology & $\begin{array}{c}\text { Number of } \\
\text { Trees }\end{array}$ & $\begin{array}{c}\text { Number of } \\
\text { Cores }\end{array}$ & $\begin{array}{c}\text { Time Span } \\
\text { Covered }\end{array}$ \\
\hline Damage Class 0 Loblolly Pine & 45 & 90 & $1924-1998$ \\
Damage Class 1 Loblolly Pine & 63 & 126 & $1912-1998$ \\
Damage Class 2 Loblolly Pine & 51 & 102 & $1907-1998$ \\
Damage Class 3 Loblolly Pine & 58 & 116 & $1882-1998$ \\
Damage Class 0 S. Red Oak & 45 & 90 & $1901-1998$ \\
Damage Class 1 S. Red Oak & 42 & 84 & $1902-1998$ \\
Damage Class 2 S. Red Oak & 48 & 96 & $1897-1998$ \\
Damage Class 3 S. Red Oak & 52 & 104 & $1889-1998$ \\
Damage Class 0 White Oak & 44 & 88 & $1859-1998$ \\
Damage Class 1 White Oak & 45 & 90 & $1842-1998$ \\
Damage Class 2 White Oak & 41 & 82 & $1811-1998$ \\
Damage Class 3 White Oak & 49 & 98 & $1828-1998$ \\
Damage Class 0 Yellow Poplar & 45 & 90 & $1901-1998$ \\
Damage Class 1 Yellow Poplar & 45 & 90 & $1915-1998$ \\
Damage Class 2 Yellow Poplar & 45 & 90 & $1910-1998$ \\
Damage Class 3 Yellow Poplar & 50 & 100 & $1911-1998$ \\
\hline
\end{tabular}

Significant temporal autocorrelation was removed by ARSTANL, but the ring width indices may still be affected by climatic variability. Graphical comparison was 
used to evaluate climatic variability from the tree ring chronologies (Figure 3). Damage class zero plots received no or minimal ice damage, therefore a drought affecting the area would be most apparent in these chronologies.

Mean growth values for the four species are equivalent to a ring width index value of 1.0 due to the standardization of the chronologies. Southern red oak and white oak showed a slight increase in radial growth in 1994 (Figure 3). Yellow poplar exhibited a slight decrease in radial growth for 1994 while loblolly pine showed the greatest reduction in 1994 ring width (Figure 3). If a drought affected the study area, then damage class zero yellow poplar would most likely experience the greatest reduction in 1994 ring width, however their ring width value was only slightly below the 30 -year mean. The decrease in loblolly pine ring width index may be due to climatic conditions, but generally loblolly pine are not as susceptible to drought as yellow poplar (Baker \& Langdon, 1990), so this large decrease may be attributed to factors other than drought. It is possible that the ring width indices for the four species were minimally affected by climatic variability, so climatic variability was quantitatively removed from ring width indices using regression to accentuate the ice storm signal. 


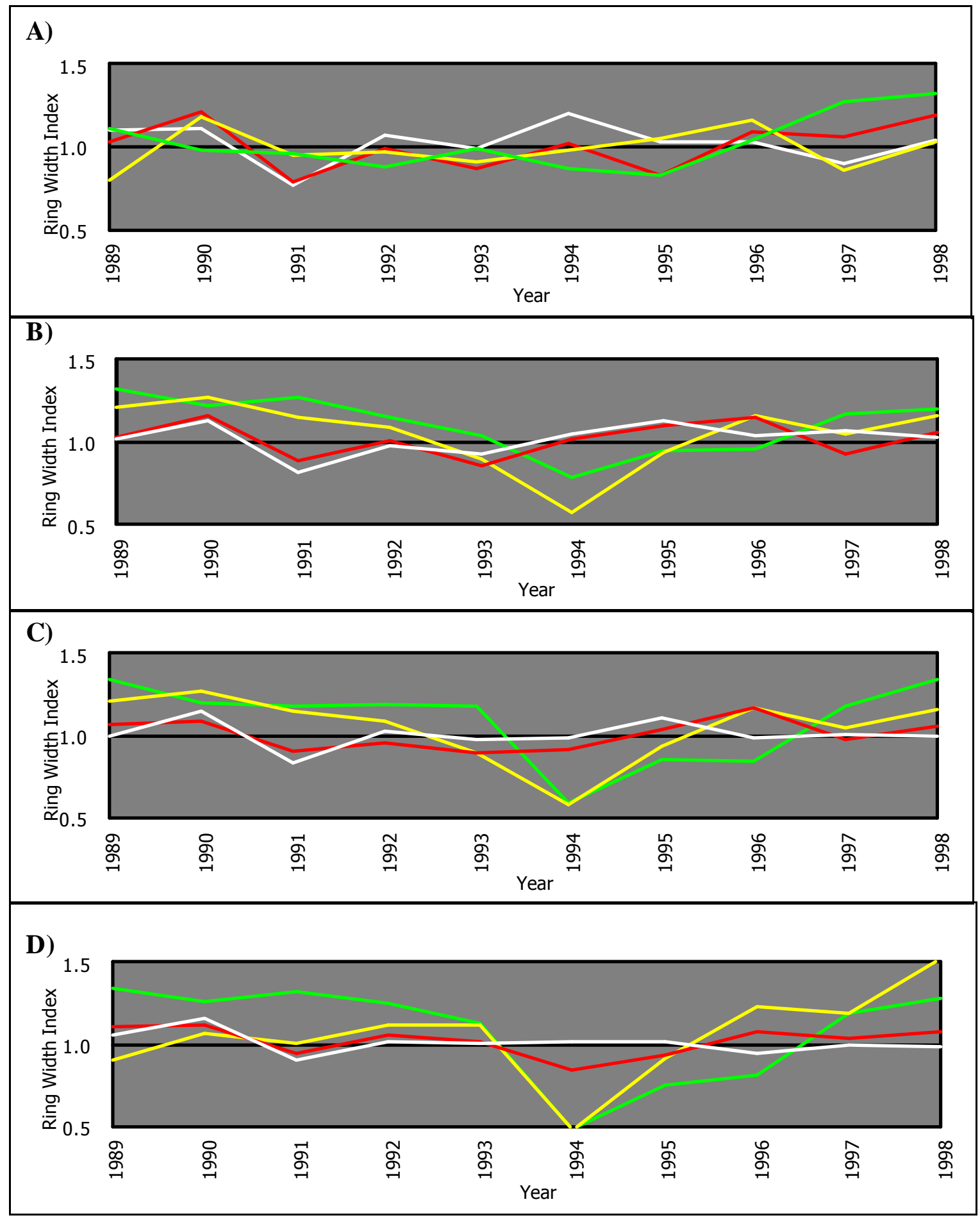

Figure 3: Standardized ring width versus year by damage class: A) Damage class zero; B) Damage class one; C) Damage class two; and D) Damage class three. Y values $>1.0$ are years of greater than mean growth, $\mathrm{Y}$ values of 1.0 are mean growth, and $\mathrm{Y}$ values $<1.0$ are years of less than mean growth, based on the 30-year period. White lines represent white oak, red lines represent southern red oak, yellow lines represent yellow poplar, and green lines represent loblolly pine. Mean growth values for all four species are equivalent to a ring width index value of 1.0 due to the standardization of the chronologies. 
The second method I used to eliminate drought from the tree ring chronologies was regression analysis. A 30-year period was used in the quantitative analysis, however the same 10-year period associated with Figure 3 (1989 to 1998) was used to illustrate the results of the regression analysis (Figure 4). The residuals are "drought free" since PDSI was used as a predictor variable in the regression model. PDSI exhibited significant relationships with growth of the chronologies $(\mathrm{P}<0.05)$ (Table 2). As a result, the decrease in residual value in 1994 is likely due to the ice storm signal rather than unusual climatic conditions as represented by PDSI. The model did a poor job predicting the annual growth of loblolly pine in damage classes one, two, and three, but did well predicting damage class zero loblolly pine radial growth. This may be an indication that the ice storm had such a dramatic effect on loblolly pine in damaged areas for so long that the disturbance washed out the PDSI signal in these three chronologies. For all other species and damage classes, the model was able to predict annual radial growth (Table 2).

All species of trees within the same damage class experienced similar crown loss, however the growth rates following the ice storm (represented by the residuals) varied among species. The differences in residual values among the four species indicate species-specific responses to the disturbance. 30-year mean growth values for all four species are equivalent to a residual value of 0.0 due to regression analysis. Note that the residuals for damage class zero trees are not relevant to the process of identifying recorders of ice damage because the trees in these plots were control plots that were not affected by the storm. 
Table 2: Results of the regression analysis used to calculate residuals by species and damage class (DC).

\begin{tabular}{lccccc}
\hline Chronology & Y Intercept & $\begin{array}{c}\text { P } \\
\text { Value }\end{array}$ & $\begin{array}{c}\text { PDSI } \\
\text { Coefficient }\end{array}$ & $\begin{array}{c}\text { P } \\
\text { Value }\end{array}$ & $\begin{array}{c}\text { Adjusted R } \\
\text { (percent) }\end{array}$ \\
\hline DC 0 Loblolly Pine & 1.033 & 0.000 & 0.047 & 0.005 & 21.8 \\
DC 1 Loblolly Pine & 1.007 & 0.000 & 0.001 & 0.930 & 0.0 \\
DC 2 Loblolly Pine & 0.996 & 0.000 & -0.010 & 0.673 & 0.0 \\
DC 3 Loblolly Pine & 0.989 & 0.000 & -0.014 & 0.592 & 0.0 \\
DC 0 S. Red Oak & 1.025 & 0.000 & 0.060 & 0.002 & 27.3 \\
DC 1 S. Red Oak & 1.010 & 0.000 & 0.030 & 0.072 & 7.7 \\
DC 2 S. Red Oak & 1.007 & 0.000 & 0.031 & 0.044 & 10.3 \\
DC 3 S. Red Oak & 1.008 & 0.000 & 0.030 & 0.018 & 14.9 \\
DC 0 White Oak & 1.044 & 0.000 & 0.044 & 0.010 & 18.3 \\
DC 1 White Oak & 1.011 & 0.000 & 0.037 & 0.001 & 27.5 \\
DC 2 White Oak & 1.009 & 0.000 & 0.035 & 0.004 & 23.1 \\
DC 3 White Oak & 0.995 & 0.000 & 0.020 & 0.056 & 9.0 \\
DC 0 Yellow Poplar & 1.037 & 0.000 & 0.062 & 0.013 & 16.9 \\
DC 1 Yellow Poplar & 1.030 & 0.000 & 0.073 & 0.003 & 24.9 \\
DC 2 Yellow Poplar & 1.025 & 0.000 & 0.066 & 0.004 & 22.1 \\
DC 3 Yellow Poplar & 1.022 & 0.000 & 0.066 & 0.007 & 19.8 \\
\hline
\end{tabular}

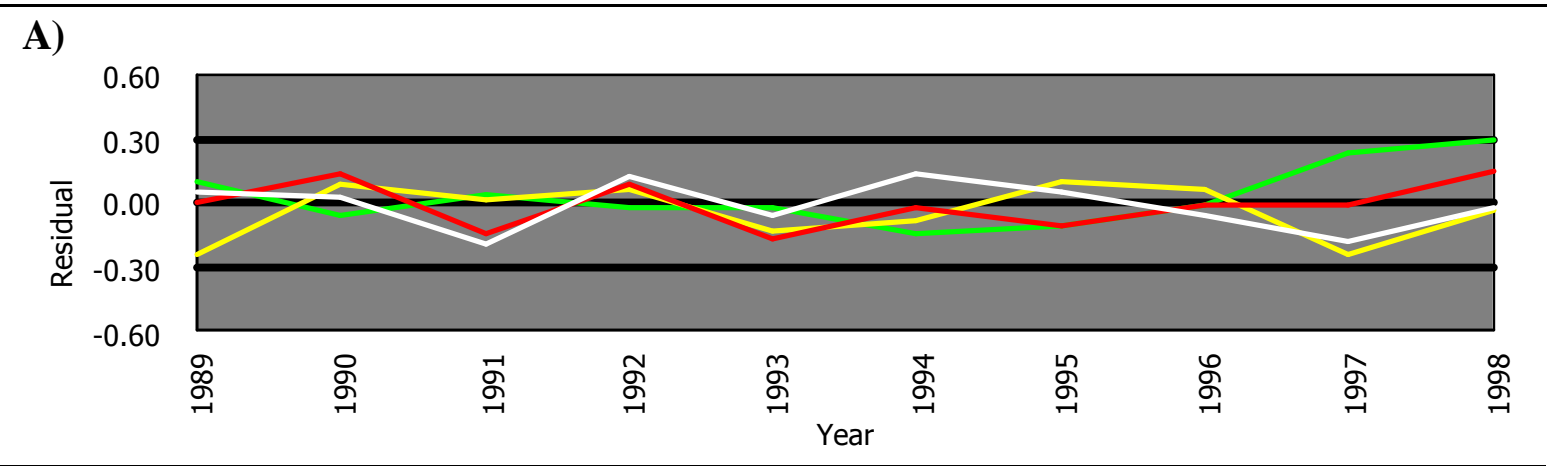

B)

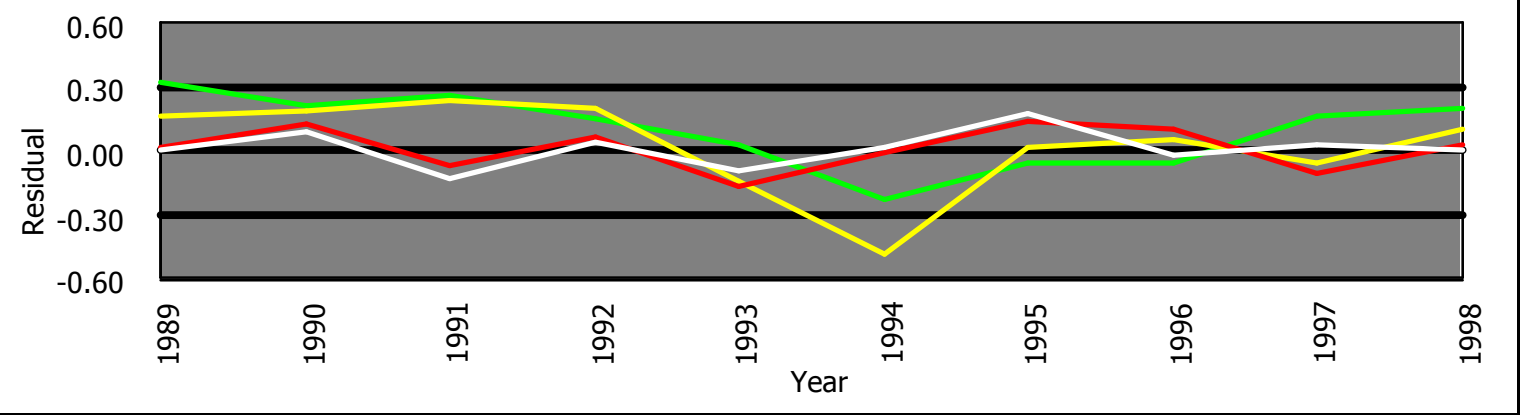



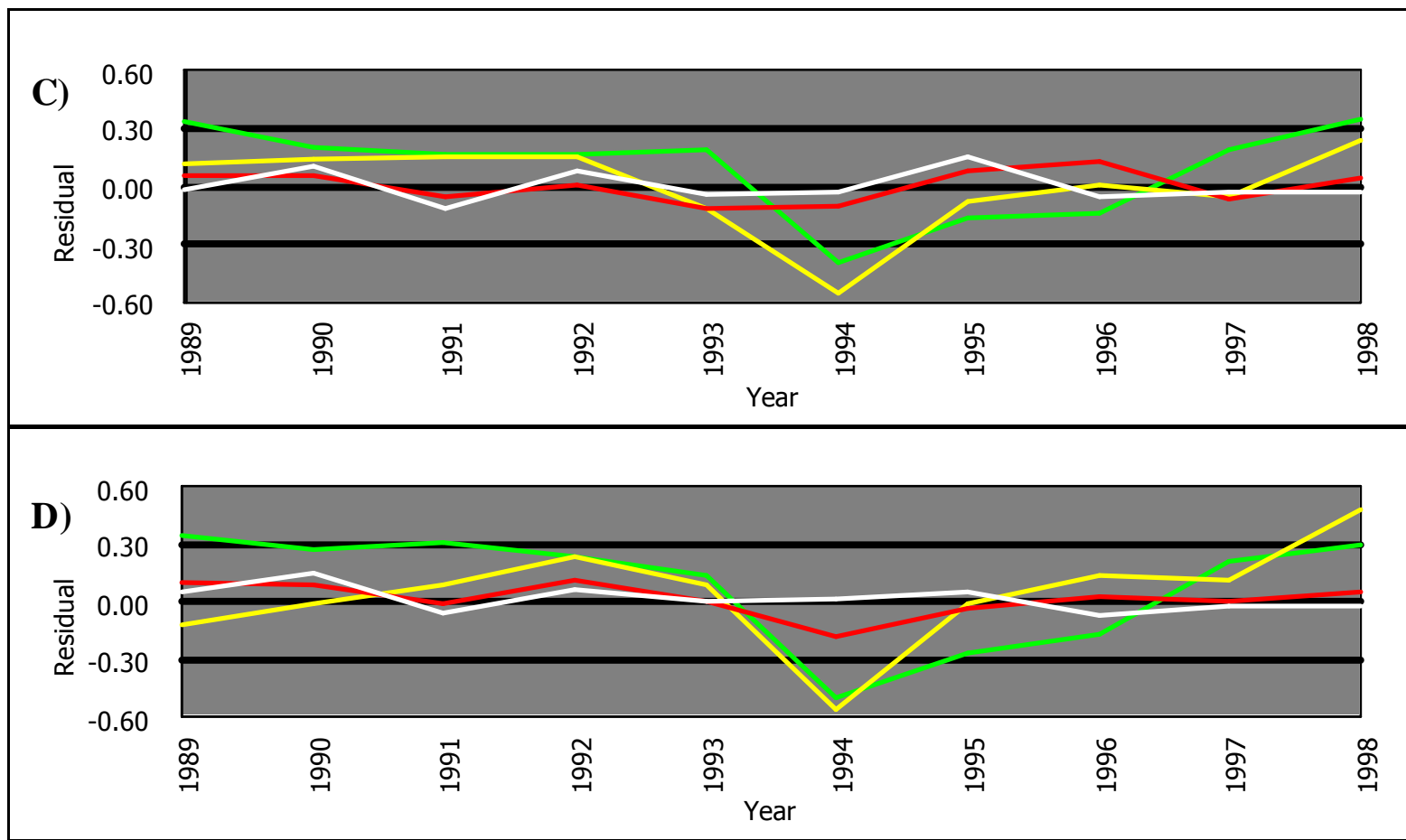

Figure 4: Residual versus year by damage class: A) Damage class zero; B) Damage class one; C) Damage class two; and D) Damage class three. Y values $>0$ are years of greater than mean growth, $\mathrm{Y}$ values of 0 are mean growth, $\mathrm{Y}$ values $<0$ are years of less than mean growth, based on the 30-year period. White lines represent white oak, red lines represent southern red oak, yellow lines represent yellow poplar, and green lines represent loblolly pine.

Only some of the species in damage class one were negatively affected by the ice storm in 1994 (Figure 4). White oak and southern red oak experienced average radial growth in 1994 when compared to radial growth values from the 30-year period used in the analysis (1968 to 1998). By 1998, southern red oak annual growth was slightly greater than the 30-year mean, while white oak experienced growth equivalent to the 30 year mean in 1998. Loblolly pine showed the second greatest reduction in radial growth in 1994, but by 1998 the annual growth for this species was the greatest among the four species in damage class one. Yellow poplar showed the largest decrease in radial growth for 1994, but by 1998 experienced the second greatest annual growth value. 
All four tree species in damage class two experienced a reduction in radial growth in 1994, but had variable responses in the four years following (Figure 4). White oak showed a slight decline in radial growth the year of the storm, and in 1998 its growth rate was slightly below the 30-year mean. In 1994, southern red oak showed a minor reduction in growth; however by 1998 southern red oak experienced growth slightly greater than the 30-year mean. Loblolly pine showed a large reduction in growth the year of the ice storm, but by 1998 loblolly pine experienced radial growth well above the 30year mean. Similar to damage class one (Figure 4), yellow poplar showed the greatest reduction in radial growth the year of the ice storm and by 1998 experienced radial growth well above the 30-year mean.

Yellow poplar, loblolly pine, and southern red oak experienced their greatest radial ring width reduction for 1994 in the damage class three category, while white oak was relatively unaffected by the ice storm in 1994 (Figure 4). White oak annual growth was slightly greater than the 30-year mean in 1994 and in 1998 experienced an annual growth rate just below the 30-year mean. Southern red oak annual growth in 1994 was below the 30-year mean, but by 1998 achieved annual growth greater than the 30-year mean. Loblolly pine showed the second largest reduction in annual growth in 1994, and by 1998 annual growth rate for loblolly pine was well above the 30-year mean. Damage class three yellow poplar exhibited the largest reduction in annual radial growth for all species in 1994. However, yellow poplar made a dramatic recovery and by 1998 this species displayed the greatest recovery of all chronologies in this study. 


\section{Best Recorders of Ice Storm Damage}

Based on the percent growth reductions in 1994, yellow poplar exhibited the greatest overall decline in 1994 radial growth, followed by loblolly pine, southern red oak, and white oak respectively (Figure 5). Southern red oak 1994 growth reduction in damage class zero and damage class one are not visible on Figure 5 due to small annual growth reduction values $(-0.7 \%$ in damage class zero and $0.0 \%$ in damage class one). Yellow poplar is the best recorder of the ice storm signal for damage classes one and two, while in damage class three loblolly pine experienced the largest percentage decline in 1994. Although yellow poplar was the overall best recorder of the ice storm signal, loblolly pine experienced the greatest reduction in overall growth during the years following the storm. Damage classes one, two, and three, loblolly pine grew less than the 30-year mean in 1994, 1995, and 1996, which was the longest continuous period of below average growth in Figure 4. Yellow poplar exhibited the greatest overall decline in radial growth, but the severity of crown damage cannot be associated with 1994 percentage growth reductions. The percentage decline in damage classes one, two, and three yellow poplar are similar, though the percentage of crown limbs destroyed in each damage class varied. Southern red oak seems to be the best species in relating percentage of crown limbs destroyed to percentage growth reduction in 1994 among the four species (Figure 5). 


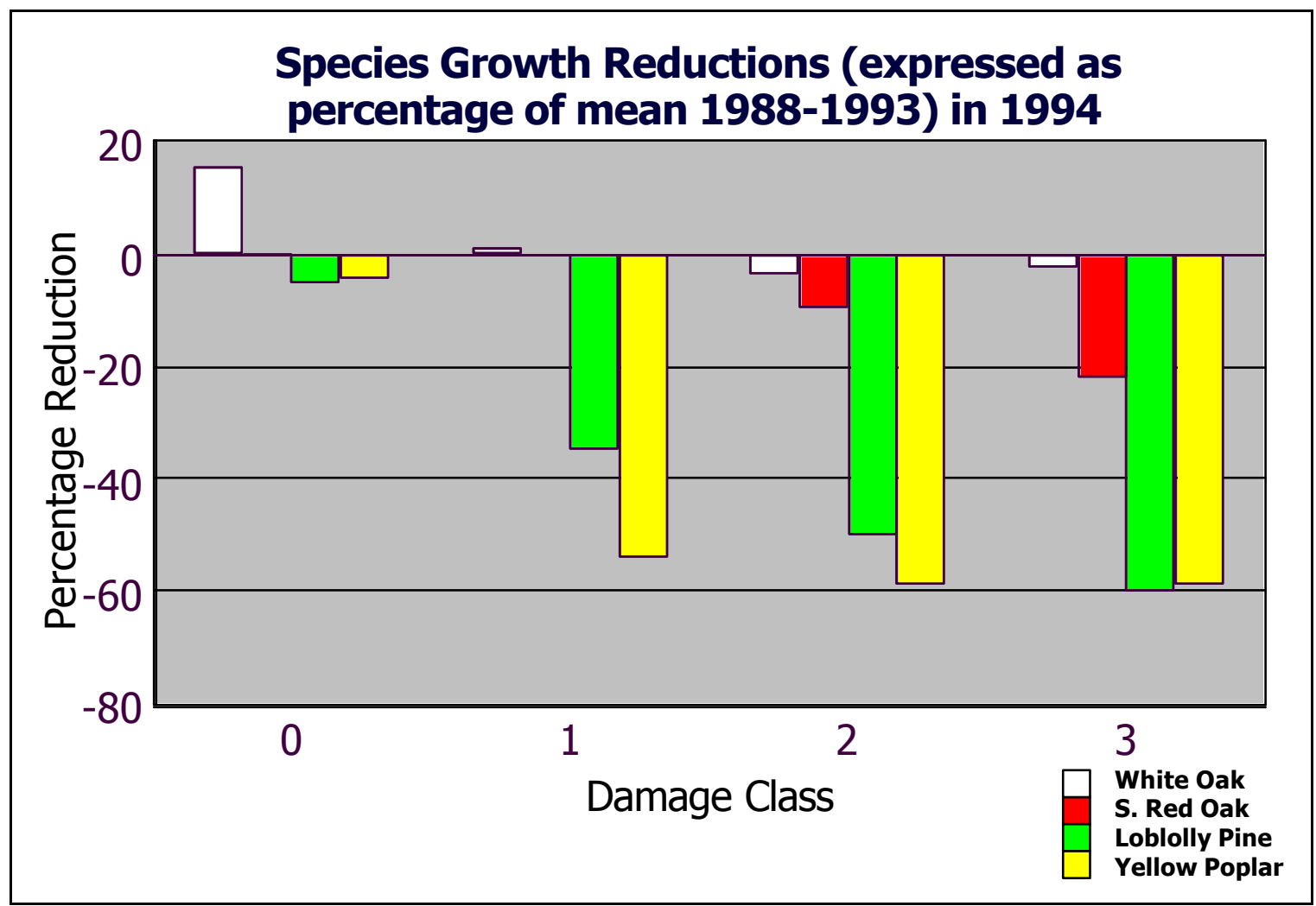

Figure 5: 1994 percentage growth reductions for individual species in each damage class.

\section{Discussion:}

Numerous studies have investigated the effect of ice storms on tree growth (Rogers, 1923; Downs, 1938; Lemon, 1961; Siccama et al., 1976; Whitney \& Johnson, 1984; Bruederle \& Stearns, 1985; Boerner et al., 1988; Hauer et al., 1993; Seischab et al., 1993; Sisinni et al., 1995; Rebertus et al., 1997; Mou, 1999; Mou \& Warrillow, 1999; Lafon \& Speer, 2002; Smith \& Shortle, 2003). Susceptibility to ice damage appears to be strongly species-specific (Abell, 1934; McCullogh, 1943; Lemon, 1961; Whitney \& Johnson, 1984), and this study supports that conclusion. However, studies often disagree on which species are the most susceptible to ice damage. Some research has shown that needle leaved species are more susceptible to ice damage (Boerner et al., 1980; Whitney \& Johnson, 1984; Mou, 1999) while other research has shown that broadleaf deciduous 
trees are more likely to be damaged by ice storms (Abell, 1934; Downs, 1938). In addition, most studies explore physical impacts on trees rather than tree growth in the years following the storm. Differences in susceptibility of individual trees may be affected by crown position, slope and aspect, which influence ice accumulation (Mou, 1999; Mou \& Warrillow, 1999; Lafon \& Speer, 2002). In fact, some species may prefer environmental positions that leave them susceptible to heavy ice accumulation. This study only included trees in the dominant or codominant strata and the topography was homogeneous throughout the study area. The results of this study therefore indicate that the differences in annual ring width indices observed here are related to the differences in species physiology rather than topographic position.

Resistance of trees to ice accumulation is attributed to many physical characteristics of the trees, such as crown geometry, wood strength, and elasticity (Mou, 1999). Linking wood strength alone to ice damage susceptibility has been attempted, but the results have not been successful (Lemon, 1961). Green wood strength for species susceptible to damage, such as black cherry (Prunus serotina) is sometimes higher than species such as red spruce (Picea rubens) that are classified as resistant to damage (U.S. Forest Service, 1955 as cited in Lemon, 1961). In addition to wood strength, moisture, growing space, decay, age, and soil conditions may affect ice storm susceptibility (US Forestry Products Laboratory, 1974).

Though most studies have explored just the immediate physical damage associated with ice accumulation, ice storm impacts on growth may be sustained for several years in some species. Radial tree growth following the 1994 ice storm also varied among the four species studied. Resistance to disease and fungi, ability to store 
food reserves, competition for resources, and the ability to produce epicormic branches may account for the varying rates of recovery in radial growth from 1994 to 1998.

The ice storm affected the annual growth rates of the four tree species differently. In all four of the damage class categories (Figures 4a-4d) in 1994, white oak showed the greatest resistance to the ice damage (in terms of radial growth) followed by southern red oak, loblolly pine (showed the greatest reduction in radial growth in damage class zero, and were second most susceptible in damage classes one, two, and three), and yellow poplar respectively. Results of previous studies that involved similar tree species also indicated that among eastern hardwood species, white oak was the most resistant to ice storm dama ge (Rogers, 1923; Downs, 1938; Whitney \& Johnson, 1984; Seischab et al., 1993). Initial damage to white oak may be less extensive because the wood of these species is resistant to breakage (Whitney \& Johnson, 1984; Rebertus et al., 1997) and their extensive root systems resist uprooting (Gale \& Grigal, 1987; Abrams, 1990). Following disturbance, white oaks may maintain consistently high radial growth because oaks have a determinate growth habit. Species within the oak family set a winter bud that contains stored food reserves from the previous growing season (Hinckley et al., 1976). These food reserves are utilized during the early part of the growing season and by the time oaks leaf-out, their addition of earlywood is complete (Kennedy \& Sutherland, 1999). After oaks have leafed-out, additional growth for the remainder of the growing season relies on currently produced photosynthates, rather than stored food reserves (Hinckley et al., 1979).

Based on growth rates (Figure 4) and calculated growth reductions for 1994 (Figure 5), yellow poplar is the best overall recorder of ice damage among the four species studied. Yellow poplar are susceptible to ice damage due to their poor bending 
strength, medium stiffness, and vulnerability to splitting (Lemon, 1961; Toenisson, 1992 as cited in Warrillow \& Mou, 1999; Perkey \& Wilkins, 2001). The results of this study are similar to others, which indicate that yellow poplar are moderately to highly susceptible to ice damage (McCarthy, 1953; Carvell et al., 1957; Lemon, 1961; Whitney \& Johnson, 1984), but contrast results of other studies where yellow poplar revealed low susceptibility to ice damage (Boerner et al., 1988; Warrillow \& Mou, 1999). The low susceptibility of yellow poplar in these studies was likely related more to topographic position in a heterogeneous topographical environment where ice damage was less severe (Boerner et al., 1988; Warrillow \& Mou, 1999).

In this study, loblolly pine was also severely affected by the ice storm though declines in annual radial growth following the ice storm were not as severe as was found for yellow poplar. In addition, different damage classes revealed different species of trees that were most susceptible to ice damage. One important difference between broadleaved deciduous species and needle leaved species relative to ice storms is the amount of canopy surface area during the winter months when ice storms generally occur. For needle leaved species, the increased canopy area due to the presence of evergreen winter foliage coupled with low flexibility and low wood strength (Rogers, 1923; Lemon, 1961) has in some cases resulted in more extensive ice damage (Whitney \& Johnson, 1984; Boerner et al., 1988; Warrillow \& Mou, 1999). The difference in physical structure between broad-leaved deciduous species and needle leaved species play an important role in ice accumulation and initial ice damage, but other factors influence the trees response in the years following an ice storm.

Tree physiology and competition for available resources can determine the growth patterns of trees following a major disturbance. Although yellow poplar experienced the 
greatest reduction in radial growth in 1994, this species recovered from the disturbance quickly (Figure 4). In 1995, yellow poplar radial growth was above the 30-year average in three of the four damage classes and in the remaining damage class, its annual radial growth for 1995 was slightly below the 30-year average. This rapid recovery following the ice storm may be due to yellow poplar's ability to produce epicormic branches. Following a disturbance where many crown limbs are destroyed, there is a sudden change in hormonal balance, which causes this species to develop epicormic branches from dormant buds along the stem and branches (Oliver \& Larson, 1996). The addition of branches and leaves to the stem of yellow poplar may have then intercepted additional solar radiation that penetrated the porous canopy, increasing the growth rate.

Epicormic branching varies by species and most needle leaved species do not have the ability to produce epicormic branches (Oliver \& Larson, 1996). As a result, the growth response of needle leaved species, including loblolly pine, is slower because these species must rely on their remaining branches to produce additional branches and leaves. The damage class one, two, and three loblolly pine did not recover to the 30-year average or above 30-year average growth until 1997 (Figure 4). However, once loblolly pine attained average or above average annual radial growth rates, their annual growth rate remained well above the 30-year average and was substantially greater than the other three species (with the exception of damage class three loblolly pine). This growth release in loblolly pine may be attributed to its crown shape, which is important in determining a tree's capability to photosynthesize energy efficiently (Oliver \& Larson, 1996). Once reestablished in the canopy, the conical crowns of loblolly pine allow for a greater canopy area per hectare than flat crowns (Oliver \& Larson, 1996). 
This study investigated the effects the ice storm had on healthy living trees for five years following the disturbance. All of the trees used in this study had survived five years following the ice storm. Trees that died from injuries inflicted by the ice damage, or by other means such as disease, were not included in the study. In addition, trees that survived the ice storm but were disease ridden or had major rot or conk were also excluded from the sample. If a large percentage of a particular tree species had died or had been classified as unhealthy based on the forest health monitoring standards used at the time of sampling, this may bias the results. For example, if many white oak died between 1994 and 1998 due to ice damage, they would not have been included in this study, thus under-representing the total number of white oak affected by the ice storm. If future researchers are solely interested in how an ice storm affects the entire community following a disturbance event, then all trees that were alive when the event occurred must be included in the sample.

Land managers are increasingly using environmental history for understanding and managing ecosystems because the natural variability of disturbance regimes may play an important role in management at the ecosystem level (Swetnam et al., 1999). Maintaining ecosystem integrity implies maintaining structural and compositional patterns, often produced by the natural disturbance regime (Mladenhoff, et al., 1993). The ice storm of 1994 was a rare event, no other major ice storms have been recorded in the area (personal communication from Dr. Mike Valenti, Forest Health Specialist for the Delaware Forest Service) therefore land managers do not have a disturbance regime from past ice storms to use as a guide for current management strategies. As a result, ecological management of rare events is problematic. Destruction caused by an ice storm can negatively affect the growth rates of trees and impact the surrounding ecosystem for 
years following the disturbance. In addition to species susceptibility, land managers may also need to consider the species-dependent ability of trees to recover to pre-storm growth rates (Smith \& Shortle, 2003). The actions taken by land managers may depend on species of trees damaged and management goals for the stands affected by the storm. The thinning of stands due to the ice storm increases the likelihood of some species of hardwoods developing epicormic branches, which produce knots in the wood. A disturbance alters growing space for surviving species by eliminating trees in the area, which leads to less competition for limited resources. Species such as yellow poplar exploit the additional growing space by producing epicormic branches. If the manager's goal is to grow trees without knots, hardwood trees with broken branches or tops over three inches in diameter should be cut during the next scheduled harvest (Oliver \& Larson, 1996; Barry et al., 1998). Alternatively, epicormic branching may be viewed as a positive phenomenon, which assists with forest recovery rates. If the study plots were to be managed for timber harvest, additional thinning or harvesting salvageable trees may be a better option to increase the amount of marketable timber per hectare.

\section{Conclusion:}

The results of this study suggest that dendrochronology is a promising method to display the relationship between ice damage and reduction in tree growth rates caused by past ice storms. In general, the four species studied showed different susceptibilities and variable growth responses to ice damage in the years following the disturbance. White oaks followed by southern red oaks showed the greatest resistance to ice damage in all four damage class categories. Loblolly pines exhibited the greatest amount of damage in the damage class zero category and were the second most susceptible species in the other 
three damage class categories. Yellow poplar showed the overall greatest reduction in radial growth the year of the storm, but also made the fastest recovery to pre-storm growth rates.

Although the methods used in this study provided results similar to previous research, particular improvements may be suggested. In future studies, investigators may consider the spatial arrangement of the study plots in order to pursue spatial analysis, such as interpolation methods, to predict growth reductions in unsampled areas. Interpolated surfaces may be utilized to: predict area most susceptible to disease or insect outbreaks due to the diminished health of trees; predict areas of fuel buildup on the forest floor; and assist in timber harvest and management. Based on the method used to create study plots, the four tree species selected for the Delaware study were not equally represented among the 75 plots. Some of the study plots incorporated a single species, while other plots were comprised of all four species. Considering that forest composition is not uniform over a large expanse, such as the state of Delaware, it may be difficult to alleviate this situation. Future researchers may aim to incorporate at least half of the species under investigation within a single study plot and must also be aware that some spatial statistical methods require a minimum and/or maximum number of samples. 


\section{References cited}

Abell, C.A. 1934. Influence of glaze storms upon hardwood forests in the southern Appalachians. Journal of Forestry 32: 35-37.

Abrams, M.D. 1990. Adaptations and responses to drought in Quercus species of North America. Tree Physiology 7: 227-238.

Asshof, R., Schweingruber, F., Wermelinger, B. 1998. Influence of a gypsy moth (Lymantria Dispar L.) outbreak on radial growth and wood-anatomy of Spanish Chestnut (Castanea Sativa Mill.) in Ticino (Switzerland). Dendrochronologia 16-17: 133-145.

Baker, J and Langdon, G. 1990. Silvics of North America Volume I Conifers. USDA Forest Service Agriculture Handbook 654. Washington D.C. pp. 497-512.

Barry, P., Doggett, C., Anderson, R., Swain Sr., K. 1998. How to evaluate and manage storm-damaged forest areas. United States Department of Agriculture Forest Service Management Bulletin R8-MB 63.

Bergeron, Y., Denneler, B., Charron, D., Girardin, M. 2002. Using dendrochronology to reconstruct disturbance and forest dynamics around Lake Duparquet, northwestern Quebec. Dendrochronologia 20: 175-189.

Biondi, F., Cayan, D., Berger, W. 1997. Dendroclimatology of Torrey Pine. The American Midland Naturalist 138: 237-251.

Biondi, F., Estrada, I.G., Ruiz, J.C., Torres, A.E. 2002. Tree growth response to the 1913 eruption of Volcan de Fuego de Colima, Mexico. Quaternary Research 59: 293-299.

Boerner, R.E.J., Runge, Shari D., Coh, Do-Soon 1988. Localized ice storm damage in an Appalachian watershed. The American Midland Naturalist 119: 199-208.

Braun, E.L. 1950. Deciduous Forests of Eastern North America. The Blankiston Company. Philadelphia and Toronto.

Bruederle, L., Streans, F. 1985. Ice storm damage to a southern Wisconsin mesic forest. Bulletin of the Torrey Botanical Club 112: 167-175.

Burleigh, J.S., Alfaro, R.I., Borden, J.H., Taylor, S. 2002. Historical and spatial characteristics of spruce budworm Choristoneura fumiferana (Clem.) (Lepidoptera: Tortricidae) outbreaks in northeastern British Columbia. Forest Ecology and Management 168: 301-309.

Carvell, W.A., Tryon, E.H., True, R.P. 1957. Effects of glaze on the development of Appalachian hardwoods. Journal of Forestry 55: 130-132. 
Colbert, J., Onken, B. 1999. Ecological conditions that affected levels of ice-storm damage in the state of Delaware, 1994 progress report. USDA Forest Service Northeastern Research Station Morgantown, West Virginia 26505.

Cook E.R., Holmes, R.L. 1986. User's manual for the program ARSTAN. International Tree Ring Data Bank library program.

Downs, A.A. 1938. Glaze damage in the birch-beech-maple-hemlock type of Pennsylvania and New York. Journal of Forestry 36: 63-70.

Fekedulegn, D., Hicks, R., Colbert, J. 2003. Influence of topographic aspect, precipitation and drought on radial growth of four major tree species in an Appalachian watershed. Forest Ecology and Management 177: 409-425.

Gale, M.R., Grigal, D.F. 1987. Vertical root distribution of northern tree species in relation to successional status. Canadian Journal of Forest Research 17: 829-834.

Glitzenstein, J.S., Harcombe, P.A., Streng, D.R. 1986. Disturbance, succession, and maintenance of species diversity in an east Texas forest. Ecological Monographs 56: 243-258.

Grissino-Mayer, H. 2001. Evaluating crossdating accuracy: A manual and tutorial for the computer program COFECHA. Tree-Ring Research 57: 205-221.

Hauer, R.J., Wang, W., Dawson, J.O. 1993. Ice storm damage to urban trees. Journal of. Arboriculture 19: 187-193.

Heidorn, K. 2001. Ice storms: Hazardous Beauty. Spectrum Educational Enterprises.

Hinckley, T.M., Thompson, D.R., McGinness, N.P., Hinckley, A.R. 1976. Stem growth and phenology of a dorminant white oak. Proceedings of the First Central Hardwood Forest Conference, Carbondale, Illinois. pp.187-202.

Ireland, W., Matthews, E. 1971. Soil Survey of Kent County, Delaware. USDA Soil Conservation Service.

Ireland, W., Matthews, E. 1974. Soil Survey of Sussex County, Delaware. USDA Soil Conservation Service.

Irland, L.C. 2000. Ice storms and forest impacts. Science of the Total Environment 262: 231-242.

Jenkins, M.A., Pallardy, S.G. 1995. The influence of drought on red oak group species and mortality in the Missouri Ozarks. Canadian Journal of Forest Research 25: 11191127. 
Kennedy, K.T., Sutherland, E.K. 1999. Fire-scar formation and compartmentalization in oak. Canadian Journal of Forest Research 29: 166-171.

Lafon, C., Speer, J. 2002. Using dendrochronology to identify major ice storm events in oak forests of southwestern Virginia. Climate Research 20: 41-54.

Lemon, P.C. 1961. Forest ecology of ice storms. Bulletin of the Torrey Botanical Club 88: 21-29.

McCarthy, E.F. 1953. Yellow poplar characteristics, growth, and management. United States Department of Agriculture technical bulletin. 35650 pp.

Mladenhoff, D.J., White, M.A., Pastor, J., Crow, T.R. 1993. Comparing spatial pattern in unaltered old growth and disturbed forest landscapes for biodiversity design and management. Ecological Applications 3: 293-305.

Mou, P. 1999. Research focuses on ice storm damage to southwest Virginia forests: Virginia Forest Landowner Update. 13: Number 4.

Mou, P., Warrillow, M.P. 2000. Ice storm damage to a mixed hardwood forest and its impacts on forest regeneration in the ridge and valley region of southwest Virginia. Journal of the Torrey Botanical Society 127: 66-82.

National Climatic Data Center (NCDC) 2003. http://www.wolrdclimate.com/cgibin/grid.pl?gr=n39w075

Oladipo, E.O. 1985. A comparative performance analysis of three meteorological drought indices. Journal of Climate 5: 655-664.

Oliver, C., Larson, B. 1996. Forest Stand Dynamics Update Edition John Wiley \& Sons, Inc.

O'Neil, L. 1963. The suppression of growth rings in jack pine in relation to defoliation by the swaine jack-pine sawfly. Canadian Journal of Botany 41: 227-235.

Orwig, D.A., Abrams, M.D. 1997. Variation in radial growth responses to drought among species, site, and canopy strata. Trees 11: 474-484.

Perkey, A.W., Wilkins, B.L. 2001. Crop Tree Filed Guide: Selecting and Managing Crop Trees in the Central Appalachians. USDA Forest Service Northeastern Research Station Morgantown, West Virginia 26505.

Rebertus, A.J., Shifley, S.R., Richards, R.H., Roovers, L.M. 1997. Ice storm damage to an old-growth oak-hickory forest in Missouri. American Midland Naturalist 137: 48-61.

Rhoades, R.W. 1995. Succession in a mature oak forest in southwest Virginia. Castanea 60: $98-106$. 
Rogers, W.E. 1923. Resistance of trees to ice storm injury. Torreya 23: 95-99.

Runkle, J.R.1985. Disturbance regimes in temperate forests. Chapter 2. In: S. T. A. Pickett and P.S. White. (eds.), The Ecology of Natural Disturbance and Patch Dynamics. Academic Press, Inc. New York. pp. 17-34.

Seischab, F.K., Bernard, J.M., Eberle, M.D. 1993. Glaze storm damage to western New York forest communities. Bulletin of the Torrey Botanical Club 120: 64-72.

Siccama, T.G., Weir, G. Wallace, K. 1976. Ice damage in a mixed hardwood forest in Connecticut in relation to Vitis infestation. Bulletin of the Torrey Botanical Club 103: 180-183.

Sisinni, S.M., Zipperer, W.C. Pleniger, A.G. 1995. Impacts from a major ice storm: street tree damage in Rochester, New York. Journal of Arboriculture 21: 156-167.

Smith, K., Shortle, W. 2003. Radial growth of hardwoods following the 1998 ice storm in New Hampshire and Maine. Canadian Journal of Forest Research 33: 325-329.

Speer, J., Swetnam, T., Wickman, B., Youngblood, A. 2001. Changes in pandora moth outbreak dynamics during the past 622 years. Ecology 82: 679-697.

Stahle, D.W., Cleaveland, M.K., Hehr, J.G. 1985. A 450-year drought reconstruction for Arkansas, United States. Nature 316: 530-532.

Strahler, A. and Strahler, A. 2000. Introducing Physical Geography Second Edition. John Wiley \& Sons Inc. New York.

Swetnam, T.W., Lynch, A. 1993. Multicentury, regional-scale patterns of western spruce budworm outbreaks. Ecological Monographs 63: 399-424.

Swetnam, T.W., Allen, C.D., Betancourt, J.L. 1999. Applied historical ecology: using the past to manage for the future. Ecological Applications 9: 1189-1206.

Taylor, R. 1981. Tree-ring analysis in forest productivity studies: an investigation of growth-climate relationships in the New Forest, Hampshire. Journal of Biogeography 8: 293-312.

Toenisson, R.L. 1992. A collection of wood properties. Technical Note B65, TVA/LR/NRM 92/3, Forest Research Development Program. TVA. Norris, TN 20 pp.

US Forest Service. 1955. Wood Handbook. USDA Agriculture Handbook No. 72 67-104.

US Forest Products Laboratory. 1974. Wood handbook: Wood as an engineering material. USDA Agriculture Handbook. 
Veblen, T.T. 1986. Treefalls and the coexistence of conifers in subalpine forests of the central Rockies. Ecology 67: 644-649.

Warrillow, M., Mou, P. 1999. Ice storm damage to forest tree species in the ridge and valley region of southwestern Virginia. Journal of the Torrey Botanical Society 126: 147-158.

Wells, N., Goddard, S., Hayes, M. 2004. A self-calibrating palmer drought severity index. Journal of Climate 17: 2335-2351.

Whitney, H.E., Johnson, W.C. 1984. Ice storms and forest succession in southwestern Virginia. Bulletin of the Torrey Botanical Club 111: 429-437.

Wolfe, J.T., Wareham, R.T., Scofield, H.T. 1949. Microclimates and macroclimates of Neotoma, a very small valley in central Ohio. Ohio Biological Survey Bulletin 41: 1267. 